\title{
Factors Influencing Green Purchase Intention of Students: A Case Study at Vietnam National University of Agriculture
}

\author{
Chu Thi Kim Loan
}

Faculty of Accounting and Business Management, Vietnam National University of Agriculture, Hanoi 131000, Vietnam

\begin{abstract}
The objective of the paper was to analyze factors influencing the green purchase intention of students through a case study at the Vietnam National University of Agriculture (VNUA), Hanoi, Vietnam. The primary data were collected from a survey of 121 undergraduate students in 2020. The study employed descriptive statistics, exploratory factor analysis (EFA), and multiple regression analysis. The survey indicated that VNUA students were highly concerned about the environment. Their green buying intention was significantly and positively affected by two groups of factors, including: (i) social influence and product knowledge; and (ii) environmental concerns and subjective norms; in which, the later group of factors has shown greater effects in this study. The study would help managers in formulating and implementing key measures to encourage students' green purchase.
\end{abstract}

\section{Keywords}

Green purchase intention, students, factor scores, multiple regression

\section{Introduction}

Today, environmental problems are still the main worry for the whole world and human beings. Air pollution, conservatory effects, and ecological unbalance are the main environmental problems that have occurred so far as the consequences of human activities (Sharma, 2011). Humans now have to face environmental pollution and suffer from severe climate change. An image of a dead whale with $40 \mathrm{~kg}$ of plastic bags inside its stomach in the Philippines (Dalton, 2019), or the status of worse drought and salinity in Vietnam's Mekong Delta last year, etc., has raised an urgent warning bell about environmental problems. People need to take prompt actions against the widespread use of environmentally unfriendly products. In other words, both producers and consumers should pay more attention to green products, of which consumers play a large role in environmental protection. This is supported by the evidence 
that $30-40 \%$ of environmental degradation has been brought about by the consumption activities of private households (Grunert, 1993). According to Bray et al. (2011), although the number of individuals willing to purchase green products has increased in the last few years, there is little evidence to suggest that purchase of green products has increased; despite environmental concern and positive attitude of customers towards sustainability and green products, market share of green products remains confined to just $1-3 \%$ of the entire market.

In Vietnam, the government has been implementing a number of activities related to sustainable production and consumption. Some documents were signed and enacted such as the International declaration and national action plan on sustainable production and consumption; the Law No. 50/2010/QH12 on economical and efficient use of energy; and Decision No. 1393 on National strategy on green growth for the 2011-2020 period with a vision to 2050; etc. Despite being in place, their actual effectiveness at the implementation level was still limited (Hoang Thi Bao Thoa, 2016). Reitman (1992) also found that producers have reacted to consumers' growing environmental consciousness by developing green products. Nevertheless, only a few green products have been successfully developed. In another study, Kirmani \& Khan (2016) emphasized that, "As of now, green products are expensive due to lack of economies of scale and slow adoption of cutting edge green technology. Hence, there is a pressing need to identify factors that can influence consumers' decision to pay a premium for the purchase of green products".

Vietnam National University of Agriculture (VNUA) is the leading national university in human resource training and research on agriculture and rural development which is considered to be a large-scale multidisciplinary university in Vietnam. VNUA annually enrolls around 6,000 undergraduate freshmen and roughly 1,200 other candidates (VNUA, 2020). The total numbers of VNUA's undergraduate students in April 2020 were about 18,600 (FABM, 2020). This also implies that their demand for shopping is large. Generally, students are often said to be future owners of the country. They are young, dynamic, and ambitious. Ottman et al. (2006) and Tai \& Tam (1997) believed that young people are more ready than older generations to accept new and innovative ideas. Moreover, supporters of environmental protection tend to be younger (Martinsons et al., 1997). Therefore, students' knowledge, concern, and behavior towards green products play an important role in sustainable development. In Vietnam, there have been some researchers conducting studies related to this topic. For example, Hoang Trong Hung et al. (2018) analyzed factors affecting consumers' green purchase behavior in Hue city; Nguyen The Khai \& Nguyen Thi Lan Anh (2016) studied consumers' green purchase intention in Ho Chi Minh city; etc. However, they mainly focused on interviewing consumers. Therefore, this research was conducted to explore factors influencing green purchase intention of students and to make some recommendations to encourage students' green buying.

\section{Methodology}

\section{Theoretical background}

Definitions of green products and green purchase intention

The concept of a green product or environmentally friendly product has been mentioned by some previous researchers. According to Shamdasani et al. (1993), a green product is one which satisfies consumers' needs without damaging the environment and contributes towards a more sustainable world. These products are environmentally superior and have a low environmental impact. Chen \& Chai (2010) showed that green products use materials safer to the environment, are recyclable, and require less packaging.

Green purchase intentions refer to an individual's readiness to perform green buying behavior, mainly reflecting the consideration of less pollution. It is assumed to be an immediate antecedent of behavior (Wang et al., 2019).

Factors affecting green purchase intention in previous studies 
According to previous studies, green purchase intentions were affected by different factors, including environmental concerns, product knowledge/information, subject norms, social influence, environmental attitude, perceived behavior control, availability of products, and perceived consumer effectiveness, etc. (Joshi \& Rahman, 2015). Their influence levels on green buying intention were found to be different in various studies.

Hessami \& Yousefi (2013) argued that environmental concerns could be defined as an attitude towards environmental consequences. This attitude is influenced by direct personal experience, the experience of other people, and media's news. Consumers with a stronger concern for the environment are more likely to purchase products as a result of their environmental claims than those who are less concerned about environmental issues (Mainieri et al., 1997). Environmental concern is a main and determinant factor in purchasing green and organic food in a number of studies (Grunert, 1993). Laroche et al. (2001) also pointed out that consumers with higher levels of environmental concerns would be more likely to exert environmentally friendly consumption.

Green product knowledge refers to subjective knowledge that is the consumers' understanding of the environmental attributes and environmental impacts of green products (Wang et al., 2019). Barrutia \& Gilsanz (2013) figured out that consumers' product knowledge could directly influence their cognition of product attributions and evaluation criterion, which would further influence consumers' abilities to collect and handle information. As stated by Wang et al. (2019), some previous studies also pointed out that green product knowledge is often regarded as a direct predictor of green purchase intention, which implies the assumption that consumers with green product knowledge will buy green products.

Social influence refers to the effects of the social environment on consumers' green purchasing behavior. That is, how much the person gains knowledge about green products through his/her family, how much he/she discusses about environmental products with his/her friends, and how much he/she shares information about green products with their family (Finisterrado \& Raposo, 2004). Perceived behavioral control refers to the capacity of an individual to perform a given behavior (Ajzen, 1988). The results of a review by Joshi \& Rahman (2015) showed that perceived behavioral control, subjective norm, and social influence had positive effects on green purchase intention in some previous studies such as Tarkiainen \& Sundqvist (2005) and Kang et al. (2013). In addition to these factors, the availability of organic food was found to be one of the independent variables in the studies by Tarkiainen \& Sundqvist (2005) and Vermeir \& Verbeke (2008). Another factor, namely perceived consumer effectiveness (PCE), was also pointed out to positively affect green purchase intention in the research of Gupta \& Ogden (2009) and Gleim et al. (2013), etc.

\section{Research model}

\section{Hypothesis}

Based on the above discussions and characteristics of the study site, a research model was developed as shown in Figure 1. All of these factors were hypothesized to positively influence green purchase intention of the students studying at the Vietnam National University of Agriculture.

\section{Observed variables}

Most dependent variables were inherited from previous studies and were adjusted to better match the specific conditions of the study site. Specifically, they were mainly developed based on the studies of Kim \& Choi (2005), Chen \& Deng (2016), Puspitasari et al. (2018), and Hoang Trong Hung et al. (2018). Few other indicators were developed from discussions with Vietnamese specialists and students. All of the variable indicators were pretested before the official survey so that some necessary modifications could be performed. Finally, six dependent variables with 24 items were chosen (Table 1). 


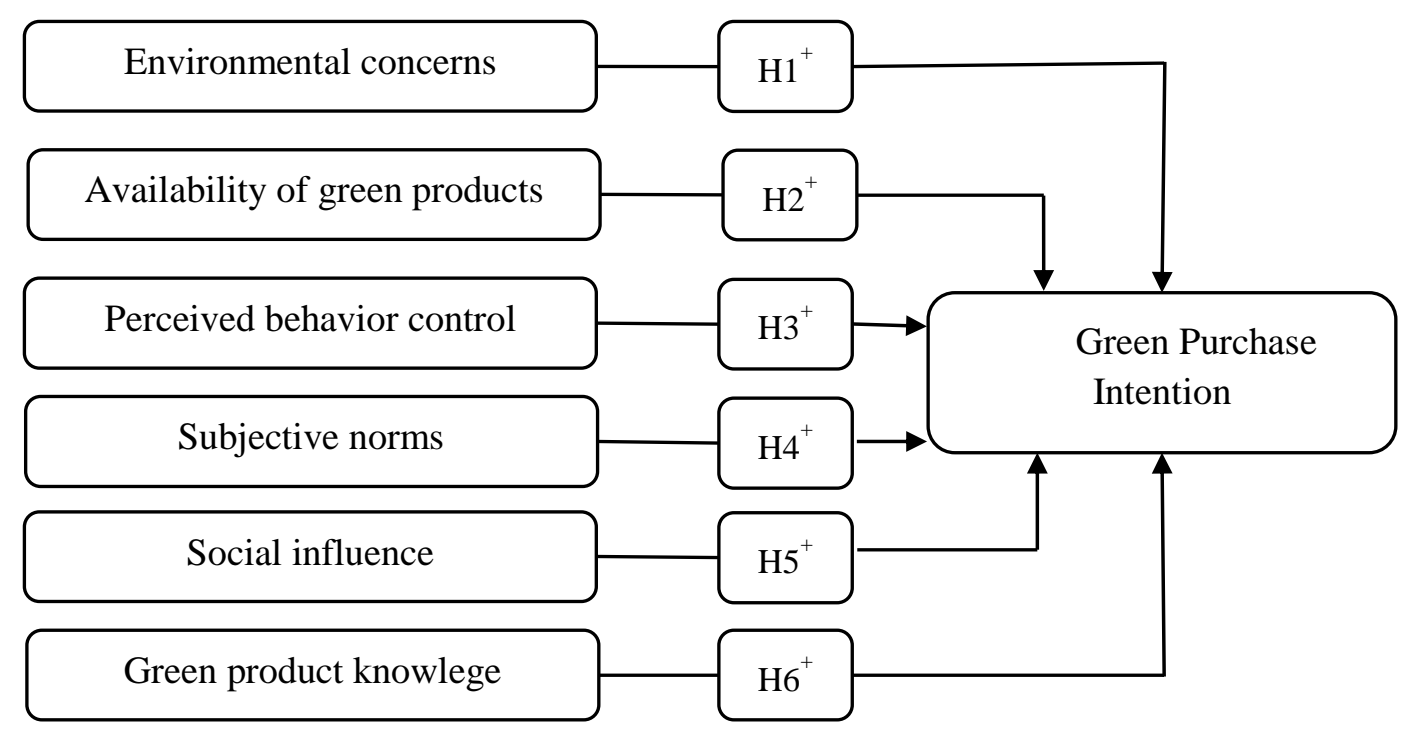

Figure 1. Research model

The indicators of the dependent variable (GPI) were mainly derived from the studies of Chen \& Deng (2016) and Puspitasari et al. (2018). The five-point Likert scale between 1 to 5 was used to measure the observed variables.

\section{Data collection and analysis}

\section{Data collection}

For the sample size, Hair et al. (1995) indicated that as a general rule, the minimum is to have at least five times as many observations as there are variables to be analyzed, and the more acceptable range would be a ten-to-one ratio. In another case, Hair et al. (2010) suggested that sample sizes should be 100 or more. Based on these arguments, and due to the cost and time limitation, with 24 independent variables used for the EFA, the expected number of samples for this study would be 140 . Only undergraduate students were chosen for the survey by convenience sampling method. An online survey was conducted in April and May 2020 to collect the primary data. A total of 135 questionnaires was obtained, of which only 121 were considered valid.

A questionnaire-based Google form was sent to the students via their emails and Microsoft Teams flatform. The questionnaire consists of two parts: personal information and students' evaluation related to the green purchase. The second part consists of seven categories. Each category contains a minimum of three statements up to a maximum of five ones. For each statement, respondents have five options to express their level of agreement: Strongly disagree, disagree, undecided, agree, and strongly agree. The respondents were required to choose only one option for each statement. Afterwards, an average point was calculated for each statement and each category separately, with 1 being the possible minimum result and 5 being the maximum possible result. The result was then concluded with an overall average.

\section{Data analysis}

\section{(i) Descriptive statistics}

Descriptive statistics in the form of percentage, mean, and frequency was used to analyze respondents' demographic characteristics and their evaluation toward green purchase.

\section{(ii) Test of Cronbach's Alpha reliability}

Cronbach's coefficient alpha is a measure of internal consistency or how closely related a set of items are. It eliminates unsatisfactory observation variables or scales in the survey. Variables that item-total correlation coefficient is less than 0.3 will be crossed out and the standard scale is Cronbach's alpha greater than or equal to 0.6 (Peterson, 1994).

(iii) Exploratory Factor Analysis (EFA) 
Table 1. Variables of the research model

\begin{tabular}{|c|c|c|c|}
\hline $\begin{array}{l}\text { Variables } \\
\text { (factors) }\end{array}$ & Variable Indicators & Code & Source \\
\hline \multirow{5}{*}{$\begin{array}{l}\text { Environmental } \\
\text { concerns (EC) }\end{array}$} & I am worried about the deterioration of Vietnam's environment. & EC1 & $\begin{array}{l}\text { Puspitasari et al. (2018) } \\
\quad \text { (Revised) }\end{array}$ \\
\hline & Mankind is severely abusing the environment. & EC2 & Kim \& Choi (2005) \\
\hline & $\begin{array}{l}\text { Environmental pollution can only be eliminated when we work } \\
\text { together. }\end{array}$ & EC3 & Hung et al. (2018) \\
\hline & $\begin{array}{l}\text { When humans interfere with nature, it often produces disastrous } \\
\text { consequences. }\end{array}$ & EC4 & Kim \& Choi (2005) \\
\hline & Humans must live in harmony with nature in order to survive. & EC5 & Kim \& Choi (2005) \\
\hline \multirow{2}{*}{$\begin{array}{l}\text { Availability of } \\
\text { green } \\
\text { products }\end{array}$} & $\begin{array}{l}\text { Green products are available at the common stores where I usually do } \\
\text { my shopping. }\end{array}$ & AV1 & Paul et al. (2016) \\
\hline & I know where green products are sold. & AV2 & $\begin{array}{l}\text { Hoang Trong Hung et al. } \\
\text { (2018) (Revised) }\end{array}$ \\
\hline$(\mathrm{AV})$ & $\begin{array}{l}\text { I do not find any inconvenience when purchasing green products } \\
\text { instead of ordinary non-green products. }\end{array}$ & AV3 & $\begin{array}{l}\text { Hoang Trong Hung et al. } \\
\text { (2018) (Revised) }\end{array}$ \\
\hline \multirow{3}{*}{$\begin{array}{l}\text { Perceived } \\
\text { behavior } \\
\text { control (PBC) }\end{array}$} & I cannot decide whether to buy a green product. & PBC1 & Chen \& Deng (2016) \\
\hline & Buying habits will have a strong impact on decision making. & PBC2 & Chen \& Deng (2016) \\
\hline & I have time to search and consider buying green products. & PBC3 & Hung et al. (2018) \\
\hline \multirow{5}{*}{$\begin{array}{l}\text { Subjective } \\
\text { norms (SN) }\end{array}$} & Environmental issues are very important to me. & SN1 & Chen \& Chai (2010) \\
\hline & $\begin{array}{l}\text { I think green products more in line with the wishes of my relatives and } \\
\text { friends. }\end{array}$ & SN2 & Chen \& Deng (2016) \\
\hline & $\begin{array}{l}\text { I think green products are consistent with the trend of social } \\
\text { development. }\end{array}$ & SN3 & Chen \& Deng (2016) \\
\hline & I think green products are more in line with my moral values. & SN4 & Chen \& Deng (2016) \\
\hline & I discuss with my friends about green products. & Sl1 & Lee (2008) \\
\hline \multirow{4}{*}{$\begin{array}{l}\text { Social } \\
\text { influence (SI) }\end{array}$} & Most of my relatives advised me to green consumer products. & $\mathrm{SI} 2$ & Developed \\
\hline & $\begin{array}{l}\text { Mass media in Vietnam provide much information about green } \\
\text { products. }\end{array}$ & $\mathrm{SI} 3$ & Developed \\
\hline & Vietnamese government is encouraging people to buy green products. & SI4 & Developed \\
\hline & I learn a lot about green products from my relatives and friends. & SI5 & Puspitasari et al. (2018) \\
\hline \multirow{4}{*}{$\begin{array}{l}\text { Green product } \\
\text { knowledge } \\
\text { (PK) }\end{array}$} & I am familiar with green products. & PK1 & Chen \& Deng (2016) \\
\hline & Green products are harmless to human and environment. & PK2 & Developed \\
\hline & $\begin{array}{l}\text { I believe in testing and identifying green products that are implemented } \\
\text { by certification organizations. }\end{array}$ & PK3 & Chen \& Deng (2016) \\
\hline & I know information about green products. & PK4 & Puspitasari et al. (2018) \\
\hline \multirow{4}{*}{$\begin{array}{l}\text { Green } \\
\text { purchase } \\
\text { intention (GPI) }\end{array}$} & I intend to buy a green product because it reduces pollution. & GPI1 & Puspitasari et al. (2018) \\
\hline & $\begin{array}{l}\text { Comparing with ordinary non-green products, I am more willing to buy } \\
\text { green products. }\end{array}$ & GPI 2 & Chen \& Deng (2016) \\
\hline & I will suggest my relatives and friends buy green products. & GPI 3 & $\begin{array}{l}\text { Hoang Trong Hung et al. } \\
\qquad(2018)\end{array}$ \\
\hline & $\begin{array}{l}\text { Next time I go shopping, it is very likely that I would choose green } \\
\text { products. }\end{array}$ & GPI 4 & Chen \& Deng (2016) \\
\hline
\end{tabular}

Factor analysis is often used to identify a small number of factors that explain most of the variance embedded in a large number of variables. According to Izquierdo et al. (2014), 
Table 2. Five-point Likert scale

\begin{tabular}{cccc}
\hline Mean & Level & Mean & Level \\
\hline $1.00-1.80$ & Strongly disagree & $3.41-4.20$ & Agree \\
$1.81-2.60$ & Disagree & $4.21-5.00$ & Strongly agree \\
$2.61-3.40$ & Undecided & & \\
\hline
\end{tabular}

the first step in conducting an EFA is to determine whether or not the data collected are adequate for this type of analysis, specifically determining whether the data are factorable. The first of these is the Kaiser-Meyer-Olkin (KMO) test that yields a qualitative index of the strength of relationship among variables based on zeroorder and partial correlations while measuring sampling adequacy for each variable and the overall model. KMO test values range between 0 and 1 , with higher numbers representing greater adequacy. The second a priori analysis is Bartlett's test of sphericity that estimates the degree to which the intercorrelation matrix produced is an identity matrix.

Standards applied for the EFA in this study are as follows: (1) If the value of KMO is higher than 0.5, the EFA will be appropriate; (2) All variable with communalities less than 0.50 do not have sufficient explanation; (3) The numbers of factors are determined based on the eigenvalue index. The factors with eigenvalue less than 1 will be excluded from the research model; (4) Total variance explained must be greater than 50\%; (5) In a sample size of 120 , a factor loading of 0.50 is requested for significance (Hair et al., 1995).

The EFA was used to reveal the number of factors and variables that belong to specific factors as follows:

$$
\mathrm{F}_{\mathrm{i}}=\mathrm{w}_{\mathrm{i} 1} \mathrm{X}_{1}+\mathrm{w}_{\mathrm{i} 2} \mathrm{X}_{2}+\ldots+\mathrm{w}_{\mathrm{ik}} \mathrm{X}_{\mathrm{k}}
$$

Where, $\mathrm{F}_{\mathrm{i}}$ is the factor estimation coefficients

$\mathrm{W}_{\mathrm{ik}}$ is the weight or factor score

$$
\mathrm{k} \text { is the number of variables }
$$

\section{(iv) Multivariate regression analysis}

The study used regression analysis to estimate the influences of different factors on students' green purchase intention. The regression equation has the following form:

$$
\mathrm{Y}=\mathrm{b}_{0}+\mathrm{b}_{1} \mathrm{~F}_{1}+\ldots+\mathrm{b}_{\mathrm{n}} \mathrm{F}_{\mathrm{n}}+\mathrm{u}
$$

Where, $\mathrm{Y}$ is the students' green purchase intention;

coefficients;

$b_{0}, b_{1}, b_{2} \ldots, b_{n}$ are the estimated

$\mathrm{F}_{1}, \mathrm{~F}_{2} \ldots, \mathrm{F}_{\mathrm{n}}$ are the factors affecting students' green purchase intention (identified after an application of EFA);

$\mathrm{u}$ is the stochastic error term.

\section{Results and Discussion}

\section{Overview of the respondents}

Among the total of 121 respondents, the percentages of males and females were approximately $72 \%$ and $28 \%$, respectively (Table 3). About $66 \%$ of the total sample were third- and fourth-year students. The monthly average income of the surveyed students mainly ranged from 1.5 to 3.0 VND million. In addition to family allowance, some students had a parttime job, so their income could reach over 3 VND million.

Based on VNUA's secondary data of April 2020, the percentage of the first-year students was quite similar to that of the second-, third- and fourth-year students (e.g., from 20.1 to $28.7 \%$ ). The number of over fourth-year students accounted for only $6.5 \%$ of the total population. As compared to the population's characteristics, the ratio of the first-year students in the sample was much lower. Regarding gender, the ratio of surveyed male students was also lower than that of the population (e.g., $28 \%$ as compared to $45 \%$ ). This can be explained by the fact that the study employed convenience sampling, thus the representative of the sample was affected.

\section{Factors affecting students' green purchase intention}

Testing the reliability of scales and observed variables in the model 
Table 3. The descriptive statistics of the sample

\begin{tabular}{|c|c|c|}
\hline Item & Quantity (persons) & Percentage (\%) \\
\hline \multicolumn{3}{|l|}{ 1. Gender } \\
\hline Female & 87 & 71.9 \\
\hline Male & 34 & 28.1 \\
\hline \multicolumn{3}{|l|}{ 2. Student year } \\
\hline 1st year & 7 & 5.8 \\
\hline 2nd year & 26 & 21.5 \\
\hline 3rd year & 45 & 37.2 \\
\hline 4th year & 35 & 28.9 \\
\hline Over 4 th year & 8 & 6.6 \\
\hline \multicolumn{3}{|c|}{ 3. Average income (million VND per month) } \\
\hline$<1.5$ & 16 & 13.2 \\
\hline $1.5-2.0$ & 31 & 25.6 \\
\hline $2.0-2.5$ & 21 & 17.4 \\
\hline $2.5-3.0$ & 25 & 20.7 \\
\hline Over 3.0 & 28 & 23.1 \\
\hline
\end{tabular}

Source: FAOSTAT (2018) and our calculations.

Reliability statistics was obtained by analyzing the collected data using SPSS software. The results showed that the factor of PBC had a Cronbach's alpha of 0.546 and the corrected item-total correlation coefficient of $\mathrm{PBC}_{1}$ was only 0.14 . Therefore, $\mathrm{PBC}_{1}$ was deleted from the model. After that, the reliability test of PBC was performed again. The Cronbach's Alpha coefficients of 7 factors are shown in Table 4. All of the Alpha coefficients were greater than 0.6 and the total correlation coefficients of observed items were all greater than 0.3 (the lowest value was 0.334 for $\mathrm{AV}_{1}$ ). Thus, it can be concluded that the scales for all measured factors were reliable and appropriate, and then continued to be used in factor analysis.

\section{Exploratory factor analysis}

The factor extraction method used in this study is the Principal component with Varimax rotation to extract the smallest number of factors.

Regarding the independent variables, the first EFA result indicated that 6 initial factors were grouped into four factors, which were extracted at eigenvalue of 1.161. However, the item of $\mathrm{SI}_{1}$ had a communality of 0.458 (lower than the acceptable level of 0.50). After that, the EFA continued to be implemented with the remaining items. $\mathrm{SN}_{2}$ had the same problem as $\mathrm{SI}_{1}$ (its communality was 0.498 ), so it was removed. Finally, the EFA results are shown as follows: The value for KMO was 0.877 , the Bartlett's Test had a significant value at below 0.001 ; all of the remaining items with communalities were greater than 0.50 ; the factors were extracted at eigenvalue of 1.117 and the sum of extracted variance was $67.06 \%$; the individual factor loadings were more than 0.50 . Therefore, factor analysis could be conducted successfully for data reduction. The rotated factor matrix validated the underlying dimensions of independent variables into 4 major dimensions (Table 5). Two items of $\mathrm{SN}$, namely $\mathrm{SN}_{1}$ (Environmental issues are very important to me) and $\mathrm{SN}_{3}$ (I think green products are consistent with the trend of social development), were grouped into the same dimension as EC. Then, the four significant factors were named social influence and product knowledge (10 items), 
Table 4. Cronbach's Alpha coefficients of the factors

\begin{tabular}{lcc}
\hline \multicolumn{1}{c}{ Factors } & Cronbach's alpha $(\alpha)$ & Number of items \\
\hline Environmental concerns (EC) & 0.902 & 5 \\
Availability of green products (AV) & 0.629 & 3 \\
Perceived behavior control (PBC) & 0.772 & 2 \\
Subjective norms (SN) & 0.838 & 4 \\
Social influence (SI) & 0.816 & 5 \\
Product knowledge (PK) & 0.805 & 4 \\
Green purchase intention (GPI) & 0.946 & 4 \\
\hline
\end{tabular}

Table 5. Rotated component matrix of the independent variables

\begin{tabular}{|c|c|c|c|c|c|}
\hline \multirow{2}{*}{ New names of the factors } & \multirow{2}{*}{ Item } & \multicolumn{4}{|c|}{ Component } \\
\hline & & 1 & 2 & 3 & 4 \\
\hline \multirow{10}{*}{$\begin{array}{l}\text { Social influence and product } \\
\text { knowledge }\left(F_{1}\right)\end{array}$} & $\mathrm{SI}_{5}$ & 0.788 & & & \\
\hline & $\mathrm{SI}_{2}$ & 0.781 & & & \\
\hline & $\mathrm{PK}_{4}$ & 0.750 & & & \\
\hline & $\mathrm{PK}_{1}$ & 0.748 & & & \\
\hline & $\mathrm{PK}_{3}$ & 0.726 & & & \\
\hline & $\mathrm{Sl}_{3}$ & 0.700 & & & \\
\hline & $\mathrm{PK}_{2}$ & 0.671 & & & \\
\hline & $\mathrm{SI}_{4}$ & 0.619 & & & \\
\hline & $\mathrm{AV}_{1}$ & 0.560 & & & \\
\hline & $\mathrm{SN}_{4}$ & 0.541 & & & \\
\hline \multirow{7}{*}{$\begin{array}{l}\text { Environmental concerns and } \\
\text { subjective norms }\left(F_{2}\right)\end{array}$} & $\mathrm{EC}_{3}$ & & 0.876 & & \\
\hline & $\mathrm{EC}_{5}$ & & 0.833 & & \\
\hline & $\mathrm{EC}_{1}$ & & 0.807 & & \\
\hline & $\mathrm{EC}_{2}$ & & 0.777 & & \\
\hline & $\mathrm{EC}_{4}$ & & 0.749 & & \\
\hline & $\mathrm{SN}_{3}$ & & 0.633 & & \\
\hline & $\mathrm{SN}_{1}$ & & 0.561 & & \\
\hline \multirow{2}{*}{ Product availability $\left(\mathrm{F}_{3}\right)$} & $\mathrm{AV}_{2}$ & & & 0.888 & \\
\hline & $\mathrm{AV}_{3}$ & & & 0.648 & \\
\hline \multirow{2}{*}{ Perceived behavior control $\left(\mathrm{F}_{4}\right)$} & $\mathrm{PBC}_{3}$ & & & & 0.860 \\
\hline & $\mathrm{PBC}_{2}$ & & & & 0.753 \\
\hline
\end{tabular}

environmental concerns and subjective norms ( 7 items), product availability ( 2 items), and perceived behavior norms (2 items). Four of these factors were hypothesized to have a 
positive and significant impact on green purchase intention of the students.

With regard to the dependent variable, the EFA showed that the KMO was 0.85 , the Bartlett's test was significant (Chi-square = 466.78, $P<0.001$ ). Four items converged into one dimension with the extracted variance total of $86.09 \%$, which then was still named green purchase intention (GPI).

Students' evaluation of factors affecting green purchase intention

In this section, descriptive statistics was firstly used to explore the respondents' evaluation of the items of each factor. Furthermore, component score coefficients $\left(\mathrm{w}_{\mathrm{i}}\right)$ of a factor were also calculated to determine the weights of the items. These coefficients were extracted from a component score coefficient matrix of the EFA process.

\section{(F1)}

(i) Social influence and product knowledge

Table 6 shows that the students evaluated six components of the factor $F_{1}$ at the neutral level (undecided) when their average scores ranged from 2.89 to 3.40 . Notably, about $37.2 \%$ of the surveyed students strongly disagreed and disagreed with the statement of PK1 (I am familiar with green products). Four remaining items were at the agreed level. These indicate that the students' green product knowledge was only moderate and the social influence on their green purchase was not so strong. The highest average point was devoted to $\mathrm{SI}_{4}$, while $\mathrm{PK}_{1}$ and $\mathrm{SI}_{2}$ had the lowest mean. As regards the component score coefficients $\left(\mathrm{w}_{\mathrm{i}}\right), \mathrm{PK}_{1}$ had the largest influence on the $\mathrm{F}_{1}$, followed by $\mathrm{SI}_{5}$ and $\mathrm{PK}_{4}$. If the students' evaluation towards $\mathrm{PK}_{1}$ is increased by 1 score, the factor $F_{1}$ will be enhanced by 0.194 score (the other variables are supposed to be constant). This implies that if the $F_{1}$ has a positive effect on green purchase intention, we should firstly pay attention to those items to improve the students' readiness to perform green buying.

\section{(ii) Environmental concerns and subjective norms $\left(F_{2}\right)$}

The survey result indicates that VNUA's students were highly concerned about the environment. The average scores of these items ranged from 3.9 to 4.45 (Table 7). Notably, about $71 \%$ of the survey students strongly agreed with $\mathrm{EC}_{3}$ (Environmental pollution can only be eliminated when we work together). Regarding the component score coefficient, the factor $\mathrm{F}_{2}$ was affected the most by variables of $\mathrm{EC}_{3}$ and $\mathrm{EC}_{5}$.

(iii) Product availability and perceived behavior control $\left(F_{3}\right.$ and $\left.F_{4}\right)$

The average scores of the items in the factor of product availability were around 3.1 on the five-point Likert scale (undecided). This implies that the students did not find it so easy to gain access to green products. Only one-third of the sample agreed and strongly agreed with the statement of $\mathrm{AV}_{2}$ (I know where green products are sold). Between the two items, $\mathrm{AV}_{2}$ had a higher effect on the $\mathrm{F}_{3}$ when its component score coefficient was 0.589 (Table 8). If this indicator is improved by 1 score, the factor $F_{3}$ will increase by 0.589 score (the other variables are supposed to be constant).

Both of the indicators of the factor $\mathrm{F}_{4}$ (perceived behavior control) were evaluated at the agreed level. As compared to employees or workers, students tend to have more free time, so $\mathrm{PBC}_{3}$ (I have time to search and consider buying green products) was highly evaluated. Between these items, $\mathrm{PBC}_{3}$ had a higher coefficient, so it would have a larger impact on $\mathrm{F}_{4}$.

Quantifying the effects of factors affecting students' green purchase intention

Multiple regression analysis was then used to analyze the factors $\left(\mathrm{F}_{\mathrm{i}}\right)$ affecting the students' green purchase intention (GPI). The multiple regression model employed in the study is as follows:

$$
\mathrm{GPI}=\mathrm{b}_{0}+\mathrm{b}_{1} \mathrm{~F}_{1}+\mathrm{b}_{2} \mathrm{~F}_{2}+\mathrm{b}_{3} \mathrm{~F}_{3}+\mathrm{b}_{4} \mathrm{~F}_{4}+\mathrm{u}
$$

Based on the results of the FEA, the values of the factors were calculated and saved in the form of standardized data. Therefore, both independent and dependent variables in the study were standardized ones, and then the standardized regression coefficients (beta) were used to analyze the relationship between them. 
Table 6. The students' evaluation of the factor of $F_{1}$

\begin{tabular}{llll}
\hline Item & Mean & Std. Deviation & Component score coefficient $(w)$ \\
\hline $\mathrm{PK}_{1}$ & 2.89 & 1.153 & 0.194 \\
$\mathrm{PK}_{2}$ & 3.40 & 1.085 & 0.152 \\
$\mathrm{PK}_{3}$ & 3.51 & 1.026 & 0.147 \\
$\mathrm{PK}_{4}$ & 3.05 & 1.094 & 0.187 \\
$\mathrm{SI}_{2}$ & 2.98 & 1.016 & 0.177 \\
$\mathrm{SI}_{3}$ & 3.45 & 1.118 & 0.140 \\
$\mathrm{SI}_{4}$ & 3.75 & 1.019 & 0.101 \\
$\mathrm{SI}_{5}$ & 3.33 & 1.143 & 0.192 \\
$\mathrm{AV}_{1}$ & 3.18 & 1.232 & 0.099 \\
$\mathrm{SN}_{4}$ & 3.52 & 1.246 & 0.077 \\
\hline
\end{tabular}

Note: $F_{1}=0.194 P K_{1}+0.152 P K_{2}+0.147 P K_{3}+0.187 P K_{4}+0.177 S I_{2}+0.14 S I_{3}+0.101 S_{4}+0.192 S I_{5}+0.099 A V_{1}+0.077 S N_{4}$

Table 7. The students' evaluation of the factor of $F_{2}$

\begin{tabular}{lccc}
\hline Item & Mean & Std. Deviation & Component score coefficient $(w)$ \\
\hline $\mathrm{EC}_{1}$ & 4.19 & 1.171 & 0.218 \\
$\mathrm{EC}_{2}$ & 4.28 & 1.018 & 0.194 \\
$\mathrm{EC}_{3}$ & 4.45 & 1.000 & 0.271 \\
$\mathrm{EC}_{4}$ & 3.94 & 1.157 & 0.216 \\
$\mathrm{EC}_{5}$ & 4.22 & 1.037 & 0.253 \\
$\mathrm{SN}_{1}$ & 3.93 & 1.153 & 0.072 \\
$\mathrm{SN}_{3}$ & 4.20 & 1.046 & 0.132 \\
\hline
\end{tabular}

Note: $F_{2}=0.218 E C_{1}+0.194 E C_{2}+0.271 E C_{3}+0.216 E C_{4}+0.253 E C_{5}+0.072 S N_{1}+0.132 S N_{3}$

After an application of OLS estimation, the predictive equation would be written as follows:

GPI $=0.486 \mathrm{~F}_{1}+0.552 \mathrm{~F}_{2}+0.0250 \mathrm{~F}_{3}+$ $0.013 \mathrm{~F}_{4}$

$$
t \quad(7.736) \quad(8.777) \quad(0.405) \quad(0.207)
$$

Adjusted $\mathrm{R}^{2}$ was 0.526 , which indicated that the overall regression equation explained $52.6 \%$ of the total variance, and the result was statistically significant at the 0.000 level $\left\{\mathrm{F}_{(4,116)}\right.$ $=34.275, \mathrm{P}<0.001\}$. Two estimated coefficients of $F_{1}$ (social influence and product knowledge) and $\mathrm{F}_{2}$ (environmental concerns and subjective norms) were statistically significant at the $99 \%$ confidence level. Therefore, these variables had significant impacts on the students' green purchase intention (i. e. the hypotheses stated for $F_{1}$ and $F_{2}$ were supported). In addition, the signs of the independent variables were in the hypothesized direction. This implies that we can improve these factors to increase the students' green purchase intention. Among the variables included in the model, $\mathrm{F}_{2}$ (Environmental concerns and subjective norms) had the largest effect on the students' green purchase intention (beta $=0.552$ ). The $F_{3}$ (product availability) and $F_{4}$ (perceived behavior control) variables were found to not significantly affect green purchase intention. Therefore, the hypotheses for $F_{3}$ and $F_{4}$ were rejected, although their signs were satisfied. 
Table 8. The students' evaluation of the factors of $F_{3}$ and $F_{4}$

\begin{tabular}{cccc}
\hline Item & Mean & Std. Deviation & Component score coefficient $(\mathrm{w})$ \\
\hline \multicolumn{5}{c}{ The factor of product availability $\left(\mathrm{F}_{3}\right)$} \\
$\mathrm{AV}_{2}$ & 3.05 & 1.132 & 0.589 \\
$\mathrm{AV}_{3}$ & 3.12 & 1.229 & 0.366 \\
\hline & The factor of perceived behavior control $\left(\mathrm{F}_{4}\right)$ & 0.478 \\
$\mathrm{PBC}_{2}$ & 3.69 & 1.017 & 0.600 \\
$\mathrm{PBC}_{3}$ & 3.46 & 1.049 &
\end{tabular}

Note: $F_{3}=0.589 A V_{2}+0.366 A V_{3}$ $F_{4}=0.478 P B C_{2}+0.6 P B C_{3}$

Envionmental concern is established as an important predictor of the consumers' attitude towards green products in almost all the studies. Laroche et al. (2001) pointed out that consumers with higher levels of environmental concerns would be more likely to exert environmentally friendly consumption. Environmental concerns were found to motivate the purchase of organic food products by Padel \& Foster (2005). The results of this study are consistent with those of Smith \& Paladino (2010), and Khai \& Anh (2016), who identified environmental concern and subjective norm as major drivers towards the purchase of green products. The findings also agree with the result by Puspitasari et al. (2018) and Lee (2008) that environmental concern and social influence had significant influences on green purchase intention. The result suggests that interpersonal communication and mass media vehicles are effective tools for affecting students' green purchasing intentions.

Green product knowledge plays a key role in consumers' decision to purchase green products and is often considered as a direct prerequisite variable for green purchase intention (Wang et $a l ., 2019)$. The result of this study supported the previous studies when showing a significant positive relationship between green product knowledge and green purchase intention. However, besides acting as a predictor, several researchers have also confirmed its moderating roles between green purchase attitudes and behaviors, etc. (e.g., Chen \& Deng, 2016). It was also found to have an indirect influence on consumers' green purchase intention as it affected perceived consumer effectiveness as well as green trust that further affected green purchase intention (Wang et al., 2019). Those roles of PK, however, were not tested in this research.

Some authors such as Wang et al. (2014) and Chen \& Deng (2016) found that perceived behavioral control had a significant and positive impact on purchase intention of green products. However, a study by Arvola et al. (2008) reported that perceived behavioral control and consumer green purchase intention were not related. While reviewing articles related to attitude-behavior inconsistencies, in the context of green purchasing, Joshi \& Rahman (2015) concluded, "it can be said although there is some evidence that perceived behavioral control positively influences green purchase behavior, yet further empirical investigation is warranted due to the limited research in the area".

Regarding product availability, most studies showed that limited availability and difficulties in accessing green products were major barriers to purchasing environmentally sustainable products (Joshi \& Rahman, 2015). For example, the availability of organic food was found to have a positive relation with green purchase intention in two studies performed by Tarkiainen \& Sundqvist (2005) and Vermeir \& Verbeke (2008). Although the finding of this study contrasts with the above studies, it is consistent with the research conducted by Hoang Trong Hung et al. (2018). Their hypotheses that product availability, subjective norms, and perceived behavior control had positive effects on 
consumer GPI, were also rejected because of low significant levels. This fact may be because of the students' unique characteristics. They usually have more free time than other consumers and enjoy exploring surrounding places, while their incomes are not so high.

\section{Conclusions and Implications}

The survey indicates that the students' green product knowledge was only moderate. The social influence on the students' green purchase was not so strong, especially their relatives' effect. It is a good sign to find that VNUA students were highly concerned about the environment. The students' evaluation of the availability of green products was also at a moderate level.

Based on the component score coefficients, $\mathrm{PK}_{1}$ had the largest effect on the $\mathrm{F}_{1}$ (social influence and product knowledge), while the factor $\mathrm{F}_{2}$ (environmental concerns and subjective norms) was affected the most by variables of $\mathrm{EC}_{3}$ (Environmental pollution can only be eliminated when we work together) and $\mathrm{EC}_{5}$ (Humans must live in harmony with nature in order to survive). Between the two items included in the factor $\mathrm{F}_{3}$, $\mathrm{AV}_{2}$ had a higher effect. Similarly, $\mathrm{PBC}_{3}$ (I have time to search and consider buying green products) had a larger impact on $\mathrm{F}_{4}$ (Perceived behavior control). The results imply that managers should firstly pay attention to those items to improve the students' evaluation of the factors, and then stimulate their green buying intention.

The regression analysis shows that students' green buying intention is affected significantly and positively by two variable groups, namely the F1 (social influence and product knowledge) and the $F_{2}$ (environmental concerns and subjective norms); in which, the variable of environmental concerns and subjective norms had the biggest influence on their green buying intention.

Based on the above findings, this paper makes the following recommendations to the government, companies, and universities:

Taking efforts to enhance students' green purchase intention by offering positive information about green products and advocating the green lifestyle. Specifically, the government should pay more attention to deliver information on green products by suitable tools (i.e., YouTube, social networks, training courses, and contests related to environmental protection). Universities should form green consumption norms, such as buying green office supplies and printing theses and documents in double sided papers to save natural resources, etc. In addition, lecturers should provide students with more green knowledge through lectures and extracurricular activities.

Making green products more accessibles to students. Vietnamese students generally have low incomes, so the higher prices of green products are one of the main obstacles to their green buying behavior. Therefore, companies should develop new green products at reasonable prices. Furthermore, the development of a wide distribution network for green products is also needed so that consumers, in general, and students, in particular, can purchase them more easily.

Enhancing the roles of social groups. Most of the students could decide their buying choices. However, those decisions are still affected by past experiences, families' tradition, and friends' behavior, etc. Thus, the government should do more campaigns to convince consumers that purchasing green products would make a difference in protecting the environment from further deterioration. When buying green products becomes a social trend, the students' green purchase would be positively influenced. On the other hand, companies should emphasize using authority certification of green products and designing labels carefully to create the consumers' confidence.

\section{References}

Ajzen I. (1988). Attitudes, personality, and behavior. Chicago: Dorsey Press.

Ajzen I. (2002). Constructing a TPB Questionnaire: Conceptual and Methodological Considerations. Working Paper. University of Massachusetts, Amherst.

Arvola A., Vassallo M., Dean M., Lampila P., Saba A., Lähteenmäki L. \& Shepherd R. (2008). Predicting 
intentions to purchase organic food: The role of affective and moral attitudes in the Theory of Planned Behaviour. Appetite. 50(2): 443-454.

Barrutia J. M. \& Gilsanz A. (2013). Electronic service quality and value: Do consumer knowledge related resources matter? Journal of Service Research. 16: 231-246.

Bray J., Johns N. \& Kilburn D. (2011). An exploratory study into the factors impeding ethical consumption. Journal of Business Ethics. 98(4): 597-608.

Chen K. \& Deng T. (2016). Research on the Green Purchase Intentions from the Perspective of Product Knowledge. Journal of Sustainability. Retrieved from www.mdpi.com/journal/sustainability on 15th May, 2020.

Chen T. B. \& Chai L. T. (2010). Attitude towards the Environment and Green Products: Consumers Perspective. Management and Science Engineering. 4(2): 27-39.

Dalton J. (2019). Whale that starved to death had record $40 \mathrm{~kg}$ of plastic waste in its stomach, Retrieved from https://www.independent.co.uk/news/world/asia/whal e-plastic-waste-stomach-philippines-dead-starveda8828626.html on June 29, 2020.

FABM (Faculty of Accounting and Business Management) (2020). A report of undergraduate students' scholaships in the academic year of 2019-2020, collected at the FABM office (in Vietnamese).

Finisterrado P. A. M. \& Raposo M. L. B. (2004). Determining the characteristics to profile the green consumer: an exploratory approach. International Review on Public and Nonprofit Marketing. 121-140.

Gleim M., Smith J. S., Andrews D. \& Cronin J. Jr. (2013). Against the Green: A Multi-method Examination of the Barriers to Green Consumption. Journal of Retailing. 89(1): 44-61.

Grunert S. C. (1993). Everybody seems concerned about the environment but is this concern reflected in (Danish) consumers' food choice? European Advances in Consumer Research. 1: 428-433.

Gupta S. \& Ogden D. T. (2009). To buy or not to buy? A social dilemma perspective on green buying. Journal of Consumer Marketing. 26(6): 376-391

Hair J. F, Anderson R. E., Tatham R. L. \& Black W. C. (1995). Multivariate Data Analysis with Reading (4th ed.). Prentice Hall International, Inc.

Hair J. F., Black W. C. \& Babin B. J. (2010). Multivariate data analysis: A global perspective. Pearson Prentice Hall, New Jersey.

Hessami H. Z. \& Yousefi P. (2013). Investigation of major factors influencing green purchasing behavior: Interactive approach. European Online Journal of Natural and Social Sciences. 2(4): 584-596.

Hoang Thi Bao Thoa (2016). Green Consumption in the World and Implications for Vietnam. VNU
University's Journal of Economics and Business. 32(1): 66-72 (in Vietnamese)

Hoang Trong Hung, Huynh Thi Thu Quyen \& Huynh Thi Nhi. (2018). Factors affecting consumers' green purchase behaviour in Hue city. Hue University's Journal of Economics and Development. 127(5A): 199-212 (in Vietnamese).

Izquierdo I., Olea J. \& Abad F. J. (2014). Exploratory factor analysis in validation studies: Uses and recommendations Psicothema. 26(3): 395-400.

Jewell J. D., Brown D. L., Thompson R., \& Smith G. (2010). Examining the influence of caregiver ethnicity on youth placed out of the home: Ethnicity matters for some. Children and Youth Services Review. 32: 12781284.

Joshi Y. \& Rahman Z. (2015). Factors Affecting Green Purchase Behaviour and Future Research Directions. International strategic management review. 3: 128143.

Kang J., Liu C. \& Kim S. H. (2013). Environmentally sustainable textile and apparel consumption: the role of consumer knowledge, perceived consumer effectiveness and perceived personal relevance. International Journal of Consumer Studies. 37(4): 442452.

Kim Y. \& Choi S. M. (2005). Antecedents of green purchase behavior: An examination of collectivism, environmental concern, and PCE. Advances in Consumer Research. 32: 592-599.

Kirmani M. D. \& Khan M. N (2016). Green Consumerism: A Review of Extant Literature. Pacific Business Review International. 1(2). DOI: 10.3968/j.mse.1913035X20100402.002.

Laroche M., Begeron J. \& Barbaro-Forleo G. (2001). Targeting consumers who are willing to pay more for environmentally friendly products. Journal of Consumer Marketing. 18: 503-520.

Lee K. (2008). Opportunity for green marketing: young consumers. Marketing Intelligence and Planning. 26(6): 573-586.

Mainieri T., Barnett E. G., Unipan T. R. \& Oskamp S. (1997). Green Buying: The Influence of Environmental Concern on Consumer Behavior. Journal of Social Psychology. 137(2): 189-204.

Martinsons M.G., So S. K. K., Tin C. \& Wong D. (1997), "Hong Kong and China: emerging markets for environmental products and technologies. Long Range Planning. 30(2): 277-290.

Nguyen The Khai \& Nguyen Thi Lan Anh. (2016). A study on customers' green purchase intention in Ho Chi Minh city. Ho Chi Minh city Open University's Journal of Science. 2 (47): 42-53 (in Vietnamese).

Ottman J. A., Stafford E. R. and Hartman C. L. (2006). Avoiding green marketing myopia: ways to improve consumer appeal for environmentally preferable products. Environment. 48(5): 22-36. 
Padel S. \& Foster C. (2005). Exploring the gap between attitudes and behavior: Understanding why consumers buy or do not buy organic food. British Food Journal. 107(8): 606-625.

Paul J., Modi A. \& Patel J. (2016). Predicting green product consumption using theory of planned behavior and reasoned action. Journal of Retailing and Consumer Services, 29,123-134.

Peterson R. A. (1994). A meta-analysis of Cronbach's coefficient alpha. Journal of consumer research. 21:3 81-391

Puspitasari N. B., Rinawati D. I., Suliantoro H. \& Sutrisno B. D. (2018). The effect of green purchase intention factors on the environmental friendly detergent product. E3S Web of Conference 73, 06007.

Reitman V. (1992). Green Products Sales Seem to Be Wilting. The Wall Street Journal. May 18, B1.

Shamdasani P., Chon-Lin G. \& Richmond D. (1993). Exploring green consumers in an oriental culture: Role of personal and marketing mix. Advances in Consumer Research. 20: 488-493.

Sharma Y. (2011). Changing consumer behavior with respect to green. International Journal of Multidisciplinary Research. 1(4): 152-162.
Tai S. H. C. \& Tam J. L. M. (1997). A lifestyle analysis of female consumers in Greater China. Psychology and Marketing. 14(3): 287-307.

Smith S. \& Paladino A. (2010). Eating clean and green? Investigating consumer motivations towards the purchase of organic food. Australasian Marketing Journal. 18(2): 93-104.

Tarkiainen A. \& Sundqvist S. (2005). Subjective norms, attitudes and intentions of finnish consumers in buying organic food. British Food Journal. 107(11): 808-822.

Vermeir I. \& Verbeke W. (2008). Sustainable food consumption among young adults in Belgium: Theory of planned behaviour and the role of confidence and values. Ecological Economics. 64(3): 542-553.

VNUA website (2020). General Introduction. Retrieved from https://eng.vnua.edu.vn/about-vnua/introduction on November 24, 2020.

Wang H, Ma B. \& Bai R. (2019). How Does Green Product Knowledge Effectively Promote Green Purchase Intention? Sustainability. 11(4): 1193. DOI:10.3390/su11041193.

Wang P., Liu Q. \& Qi Y. (2014). Factors influencing sustainable consumption behaviors: a survey of the rural residents in China. Journal of Cleaner Production. 63: 152-165. 